\title{
PENINGKATAN HASIL BELAJAR SISWA MELALUI PENERAPAN METODE DRILL (LATIHAN) PADA MATERI TERMOKIMIA SISWA SMA NEGERI 2 KEJURUAN MUDA
}

\author{
Israyati \\ Guru Kimia SMA Negeri 2 Kejuruan Muda Aceh Tamiang \\ Bukit Rata, Kejuruan Muda, Kabupaten Aceh Tamiang, Aceh 24476 \\ Email: israyati167@gmail.com
}

\begin{abstract}
Abstrak
Penelitian ini bertujuan untuk mengetahui: Apakah hasil belajar kimia pada materi termokimia bagi siswa kelas XI IPA. 1 pada SMA Negeri 2 Kejuruan Muda Kabupaten Aceh Tamiang dapat ditingkatkan melalui penerapan metode drill (latihan)? Metode penelitian yang digunakan adalah penelitian tindakan kelas (PTK) yang terdiri atas 2 siklus. Subyek penelitian adalah siswa kelas XI IPA 1 yang terdiri dari 28 siswa perempuan dan 12 siswa laki-laki. Analisis data menggunakan teknik analisis diskriptif komparatif dengan membandingkan kondisi awal dengan hasil-hasil yang dicapai pada setiap siklus, dan analisis deskriptif kualitatif hasil observasidengan membandingkan hasil observasi dan refleksi pada siklus I dan siklus II. Jika pada tindakan pra siklus nilai rata-rata kelas hanya 50,75, maka pada siklus 1 nilai rata-rata kelas menjadi 63,50 dan pada siklus 2 ternyata nilai rata-rata kelas menjadi 76,00. Nilai KKM yang digunakan sebagai penentu keberhasilan belajar siswa pada penelitian ini adalah 70. Pada tindakan pra siklus, siswa yang memiliki nilai dibawah KKM 70, sebanyak 35 siswa $(87,5 \%)$. dan hanya sebahagian kecil $(12,5 \%)$ atau 5 siswa saja yang telah mencapai ketuntasan belajar dan pada akhir siklus 1 . Pada siklus 1 , masih terdapat 26 siswa $(65,0 \%)$ yang belum mencapai ketuntasan atau masih berada di bawah kriteria ketuntasan minimal (70) dan 14 siswa (35,0 \%) yang sudah mencapai ketuntasan, sedangkan pada akhir siklus 2, masih terdapat 11 siswa $(27,5 \%)$ yang belum mencapai ketuntasan dan 29 siswa $(72,5 \%)$ yang sudah mencapai ketuntasan. Adapun hasil non tes pengamatan proses belajar menunjukkan perubahan siswa lebih aktif selama proses pembelajaran berlangsung. Dengan demikian penerapan metode drill (latihan) pada materi termokimia bagi siswa kelas XI IPA 1 pada SMA Negeri 2 Kejuruan Muda Kabupaten Aceh Tamiang.
\end{abstract}

Kata Kunci : Hasil belajar, Metode drill (latihan), Termokimia

\begin{abstract}
Abstrak
This study aims to determine: Can the results of learning chemistry on thermochemistry material for class XI IPA.1 students at SMA Negeri 2 Vocational Muda Aceh Tamiang Regency be improved through the application of the drill method? The research method used is classroom action research (PTK) which consists of 2 cycles. The research subjects were students of class XI IPA 1 which consisted of 28 female students and 12 male students. Data analysis used comparative descriptive analysis technique by comparing the initial conditions with the results achieved in each cycle, and qualitative descriptive analysis of the results of the observations by comparing the results of observations and reflections in cycle I and cycle II. If in the pre-cycle action the class average value was only 50.75, then in cycle 1 the class average value was 63.50 and in cycle 2 the class average was 76.00. The KKM value used as a determinant of student learning success in this study was 70. In the pre-cycle action, there were 35 students (87.5\%) who had a score below the KKM value. and only a small proportion (12.5\%) or only 5 students who have achieved mastery learning and at the end of cycle 1.In cycle 1, there are still 26 students (65.0\%) who have not reached completeness or are still below the completeness criteria at least (70) and 14 students (35.0\%) who had reached completeness, while at the end of cycle 2, there were still 11 students (27.5\%) who had not yet achieved completeness and 29 students (72.5\%) who had reached completeness. The non-test results of the observation of the learning process show that students are more active during the learning process Thus the application of the drill method (training) on thermochemical material for class XI IPA 1 students at SMA Negeri 2 Vocational Muda, Aceh Tamiang Regency.
\end{abstract}

Keywords: learning outcomes, drill method, thermochemistry 


\section{PENDAHULUAN}

Pendidikan merupakan salah satu usaha manusia untuk memperbaiki taraf kehidupannya. Banyak tokoh masyarakat yang bukan berasal dari kalangan mampu tetapi di kemudian hari menjadi seorang pengusaha atau politikus atau tokoh yang sukses lainnya karena mempunyai tekad yang kuat untuk memperoleh dan meraih pendidikan yang baik meski harus melewati banyak cobaan dan rintangan.

Pendidikan merupakan usaha sadar manusia untuk memperoleh suatu ilmu dan keterampilan khususnya melalui suatu proses belajar mengajar. Namun tidak selamanya proses belajar mengajar tersebut dapat dicerna dengan efektif dan efisien oleh siswa. Banyak hal yang mempengaruhi keberhasilan suatu proses belajar mengajar.

Guru yang baik akan senantiasa melakukan evaluasi diri di setiap akhir tahun pelajaran mengenai proses belajar mengajar yang telah dilakukannya selama setahun tersebut. Kadang kala, ada suatu materi yang kelihatannya (menurut sang guru) bukanlah materi yang susah akan tetapi bagi kebanyakan siswa (ternyata) menjadi sangatlah susah untuk dipahami dan dimengerti. Begitu juga sebaliknya, ada suatu materi (yang bagi kebanyakan guru) merupakan materi yang sulit tetapi (ternyata) bagi siswa bukanlah materi susah karena cara penyampaian materi yang dilakukan oleh sang guru ternyata sangatlah mudah untuk dipahami dan dimengerti oleh siswa.

Cara penyampaian inilah yang seharusnya lebih diperluas dan diperdalam oleh setiap guru. Banyak cara penyampaian sederhana dapat dilakukan oleh guru untuk mempermudah siswa dalam memahami materi pembelajaran. Seorang guru harus pandai-pandai mensiasati cara penyampaian materi tersebut. Seorang guru tidak perlu merepot-repotkan diri dengan hal-hal yang membingungkan karena ternyata banyak cara sederhana yang dapat dilakukan untuk membuat variasi cara penyampaian materi pembelajaran.

Salah satu hal sederhana yang ingin penulis tekankan pada penelitian tindakan kelas ini adalah metode drill (latihan). Metode drill (latihan) ini sudah sangat sering dilakukan khususnya bagi materi pembelajaran eksakta yang memang membutuhkan banyak latihan soal. Penelitian ini menggunakan metode penelitian tindakan kelas dengan tujuan agar dapat mempermudahkan siswa dalam memahami materi pembelajarannya terutama materi kimia di kelas XI yaitu termokimia.

Materi termokimia terdiri dari konsep pemahaman akan reaksi kimia dan perhitungan kimia. Berdasarkan pengalaman penulis selama ini, materi termokimia ini merupakan salah satu materi yang (terasa) agak susah disampaikan oleh guru dan bagi siswa (terasa) susah untuk dimengerti serta dipahami secara efektif dan efisien. Kesulitan ini terkait dengan pemahaman reaksi kimia yang seharusnya sudah mereka kuasai sejak kelas $\mathrm{X}$ tetapi kenyataannya masih banyak siswa yang belum menguasai dengan mahir mengenai reaksi kimia ini. Sedangkan, masalah perhitungan kimia yang melibatkan penjumlahan angka-angka negatif dan positif, ternyata bagi kebanyakan siswa masih kurang lancar dalam penyelesaian perhitungan semacam itu.

Sehingga salah satu cara pembelajaran yang hendak dilakukan oleh penulis pada penelitian tindakan kelas ini adalah dengan melakukan metode drill (latihan). Pada akhir pembelajaran ini 
diharapkan akan lebih banyak kesempatan siswa untuk memperlancar reaksi kimia dan terbiasa menyelesaikan perhitungan kimianya. Melalui pembelajaran dengan menggunakan metode drill (latihan) ini, maka siswa akan diberikan latihan/tugas/ulangan terkait materi pembelajaran yang dilakukan secara berulang sehingga menjadi suatu kebiasaan yang positif bagi siswa tersebut. Selain itu untuk membentuk kebiasaan itu dapat dilakukan dengan menambahkan waktu dan memperluas konsep materi dan selalu memberikan remedial apabila terdapat misskonsepsi dalam proses latihan yang telah disajikan (Rusman, 2012).

Berdasarkan permasalahan diatas, peneliti melakukan penelitia mengengai Peningkatan hasil belajar siswa melalui penerapan metode drill (latihan) pada materi termokimia.

\section{METODE PENELITIAN}

Penelitian ini menggunakan metode penelitian tindakan kelas (classroom action research) yang terdiri atas 2 siklus. Setiap masing-masing siklus terdiri atas perencanaan pembelajaran, pelaksanaan pembelajaran, pengamatan dan refleksi.

Penelitian dilaksanakan di SMA Negeri 2 Kejuruan Muda Kabupaten Aceh Tamiang pada kelas XI IPA 1 Tahun Pelajaran 2017/2018.

Subyek penelitian adalah siswa kelas XI IPA 1 yang terdiri dari 28 siswa perempuan dan 12 siswa laki-laki. Adapun karakteristik siswa berdasarkan pengamatan penulis ialah rendahnya hasil belajar siswa pada mata pelajaran kimia dan tingkat kecerdasan yang tidak jauh berbeda ( rata-rata sedang ).

Teknik pengumpulan data menggunakan data hasil tes tertulis.Tes tertulis diberikan pada setiap akhir siklus dengan konsep materi termokimia. Tes tertulis digunakan pada akhir siklus 1, terdiri atas materi termokimia 1 sedangkan tes tertulis yang digunakan pada akhir siklus 1I, terdiri atas materi termokimia 2.

Tabel 1. Sebaran materi tiap pertemuan pada siklus 1 dan 2

\begin{tabular}{|l|c|l|l|}
\hline No. & Siklus & Pertemuan & Materi \\
\hline 1. & 1 & 1 & $\begin{array}{l}\text { Konsep termokimia } \\
\text { (pengertian, jenis } \\
\text { reaksi, jenis } \\
\text { perubahan entalpi) } \\
\text { Perhitungan } \\
\text { termokimia (Hukum } \\
\text { Hess)(grafik) }\end{array}$ \\
\hline 2. & 2 & 1 & $\begin{array}{l}\text { Perhitungan } \\
\text { termokimia }\left(\Delta \mathrm{H}_{\mathrm{f}}\right) \\
\text { Perhitungan } \\
\text { termokimia (energy } \\
\text { ikatan) }\end{array}$ \\
\hline
\end{tabular}

Sedangkan teknik pengumpulan data mengguunakan non tes meliputi teknik observasi dan dokumentasi. Lembar Observasi yang diberikan pada saat pelaksanaan penelitian bertujuan untuk melihat sejauh mana kemampuan siswa dalam memahami materi Konsep termokimia (pengertian, jenis reaksi, jenis perubahan entalpi) dan Perhitungan termokimia (Hukum Hess) pada siklus 1 dan Perhitungan termokimia $\left(\Delta \mathrm{H}_{\mathrm{f}}\right)$ dan Perhitungan termokimia (energy ikatan) pada siklus 2. Sedangkan teknik dokumentasi digunakan untuk mengumpulkan data khususnya nilai mata pelajaran kimia.

Teknik analisis data yang digunakan dalam penelitian ini adalah teknik analisis deskriptif, yang meliputi:

1. Analisis deskriptif komparatif hasil belajar dengan cara 
membandingkan hasil belajar pada siklus 1 dan 2 serta membandingkan masing-masing indikator pada siklus 1 dan 2.

2. Analisis deskriptif kualitatif dengan cara membandingkan hasil observasi dan refleksi pada siklus 1 dan 2.

\section{HASIL DAN PEMBAHASAN}

Berdasarkan hasil kemampuan awal siklus 1 dan 2 dapat terlihat adanya perbedaan jumlah siswa yang masih di bawah Kriteria Ketuntasan Minimal. Pada pra siklus, jumlah siswa yang dibawah KKM sebanyak 35 siswa $(87,5 \%)$ dan pada akhir siklus 1 berkurang menjadi 26 siswa $(65,0 \%)$ sedangkan pada akhir siklus 1I siswa yang masih mempunyai nilai di bawah KKM (70) hanya 11 siswa $(27,5 \%)$. Jumlah siswa yang mencapai ketuntasan belajar mengalami peningkatan jika dibandingkan dengan siklus 1 , seperti disajikan dalam Tabel 2. berikut ini.
Tabel 2. Perbandingan Hasil Nilai Tes Prasiklus ,Siklus 1 dan Siklus 2

\begin{tabular}{|c|c|c|c|c|}
\hline \multirow[t]{2}{*}{ No } & \multirow{2}{*}{$\begin{array}{c}\text { Hasil } \\
\text { tes }\end{array}$} & \multicolumn{3}{|c|}{ Nilai siswa } \\
\hline & & $\begin{array}{c}\text { Pra } \\
\text { siklus }\end{array}$ & $\begin{array}{c}\text { Siklus } \\
1\end{array}$ & $\begin{array}{c}\text { Siklus } \\
2\end{array}$ \\
\hline 1. & 30 & 1 & - & - \\
\hline 2. & 40 & 11 & 8 & - \\
\hline 3. & 50 & 20 & 10 & 7 \\
\hline 4. & 60 & 3 & 8 & 4 \\
\hline 5. & 70 & 2 & 9 & 9 \\
\hline 6. & 80 & 3 & 3 & 10 \\
\hline 7. & 90 & - & 2 & 7 \\
\hline 8. & 100 & - & - & 3 \\
\hline & Jumlah & 40 & 40 & 40 \\
\hline $\begin{array}{l}\text { Rata } \\
\text { Kela }\end{array}$ & & 50,75 & 63,50 & 76,00 \\
\hline
\end{tabular}

Peningkatan hasil tes kemampuan belajar siswa ini dapat ditunjukkan dengan Gambar 1. dibawah ini :

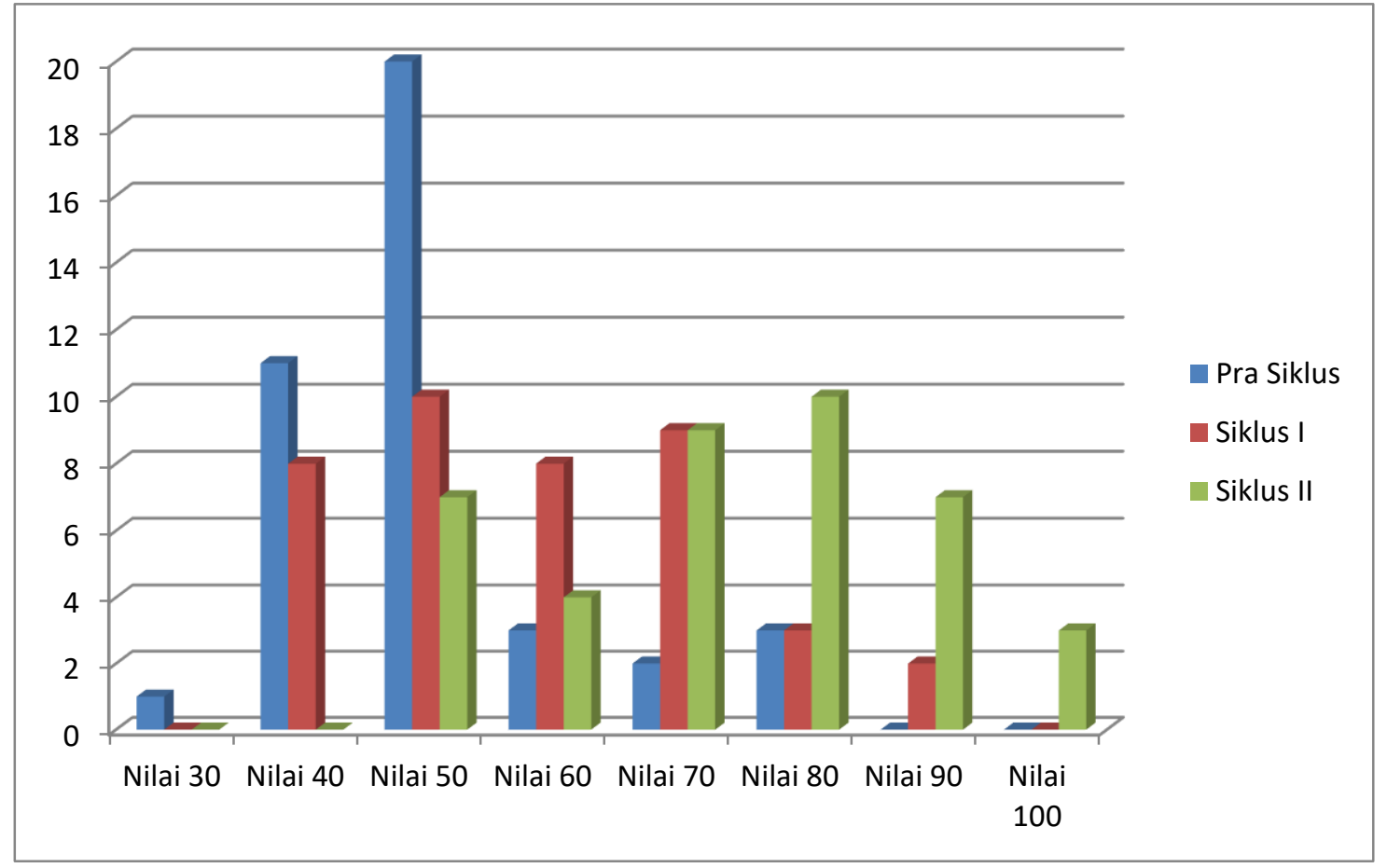

Gambar 1. Grafik Perbandingan Hasil Nilai Tes Pra Siklus, Siklus 1 dan Siklus 2 
Nilai rata-rata kelas juga meningkat sejak tindakan pra siklus, siklus 1 hingga 2. Jika pada tindakan pra siklus nilai rata-rata kelas hanya 50,75, maka pada siklus 1 nilai rata-rata kelas menjadi 63,50 dan pada siklus 2 ternyata nilai rata-rata kelas menjadi 76,00. Peningkatan nilai rata-rata kelas dapat ditunjukkan dengan tabel 2 berikut ini.

Tabel 2. Perbandingan nilai rata-rata kelas pada pra siklus, siklus 1 dan siklus 2

\begin{tabular}{|c|c|c|}
\hline No. & Tindakan & Nilai rata-rata kelas \\
\hline 1. & Pra siklus & 50,75 \\
\hline 2. & Siklus 1 & 63,50 \\
\hline 3. & Siklus 1I & 76,00 \\
\hline
\end{tabular}

Tabel peningkatan nilai rata-rata kelas dapat diperjelas dengan Gambar 2. dibawah ini :

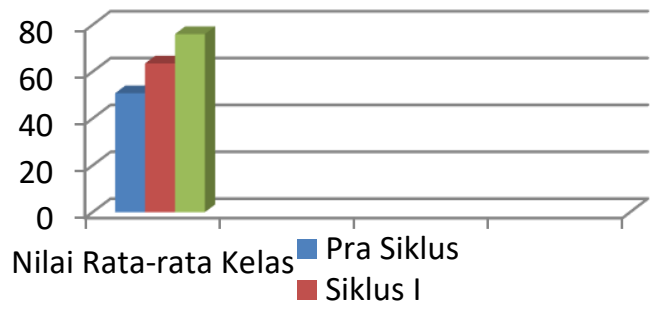

Gambar 2. Grafik Perbandingan ratarata kelas pada prasiklus, siklus 1 dan siklus 2

Perbandingan ketuntasan belajar siswa pada pra siklus, siklus 1 dan siklus 2 dapat dilihat pada tabel berikut ini.

Tabel 3. Perbandingan Ketuntasan Belajar Siswa Pada Kegiatan Prasiklus, siklus 1 dan siklus 2

\begin{tabular}{|c|c|c|c|c|c|c|c|}
\hline \multirow{2}{*}{ No } & \multirow{2}{*}{ Ketuntasan } & \multicolumn{6}{|c|}{ Jumlah Siswa } \\
\cline { 3 - 8 } & & \multicolumn{2}{|c|}{ Prasiklus } & \multicolumn{2}{|c|}{ Siklus 1 } & \multicolumn{2}{c|}{ Siklus 2 } \\
\cline { 3 - 8 } & Jumlah & $\mathbf{( \% )}$ & Jumlah & $(\boldsymbol{\%})$ & Jumlah & $(\%)$ \\
\hline 1. & Tuntas & 5 & 12,5 & 14 & 35,0 & 29 & 72,5 \\
\hline 2. & Belum Tuntas & 35 & 87,5 & 26 & 65,0 & 11 & 27,5 \\
\hline & Jumlah & 40 & 100 & 40 & 100 & 40 & 100 \\
\hline
\end{tabular}

Tabel perbandingan ketuntasan dapat diperjelas pada Gambar 3 dibawah :

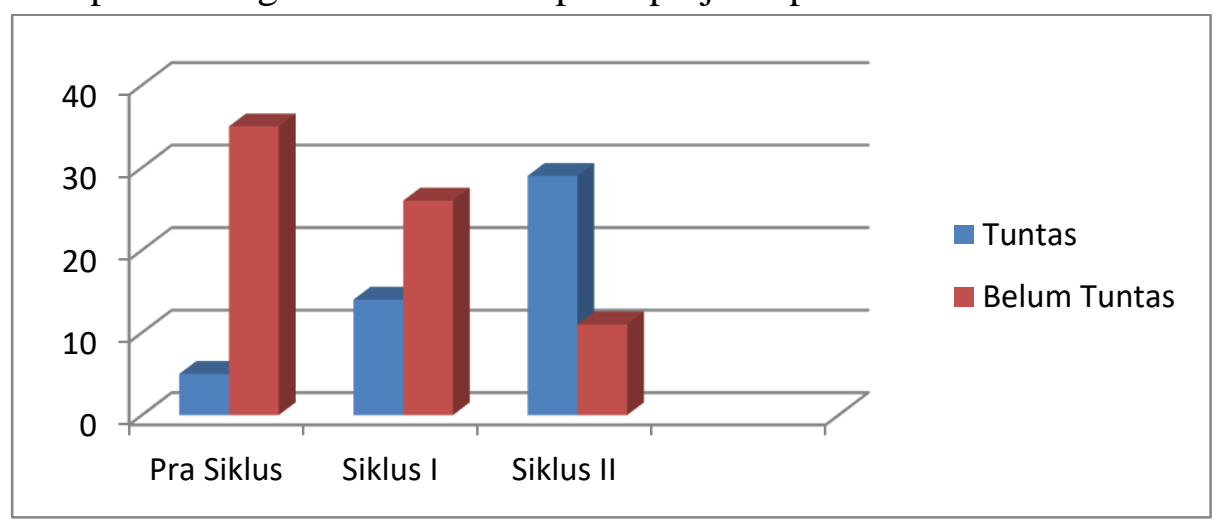

Gambar 3. Grafik Ketuntasan Belajar Siswa pada prasiklus, siklus 1 dan siklus 2

Berdasarkan Gambar 3, dapat disimpulkan bahwa penerapan metode drill (latihan) dapat meningkatkan hasil belajar siswa, khususnya pada kompetensi dasar materi termokimia.

Berdasarkan hasil observasi guru dalam kegiatan pembelajaran ini sudah 
sebagian besar siswa menyadari bahwa proses pembelajaran ini berbeda dari proses pembelajaran biasanya. Karena pada proses pembelajaran ini semua siswa berusaha untuk menguasai materi melalui drill (latihan) menggunakan lembar kerja siswa yang telah diberikan oleh guru baik secara mandiri maupun kelompok tanpa mengharapkan terlalu banyak bantuan dari guru. Jadi guru mulai mengembangkan student centered dan mulai mengurangi teacher centered.

Dan siswa-siswa tersebut juga berusaha untuk dapat berbagi informasi yang mereka peroleh tersebut jika salah satu anggota kelompok sudah dapat menguasai suatu materi seperti tertera dalam lembar kerja siswa. Ternyata motivasi dan bimbingan yang terus menerus diberikan oleh guru memberikan hasil yang maksimal pada akhir pembelajaran pada siklus 2 .

Dari hasil penelitian, maka telah terlihat peningkatan pemahaman pada pada materi termokimia pada siswa kelas XI IPA.1 SMA Negeri 2 Kejuruan Muda melalui penerapan metode drill (latihan). Peningkatan nilai rata- rata pada pra siklus, siklus 1 dan siklus 2 yaitu 50,75 menjadi 63,50 dan meningkat lagi menjadi 76,00.

Pada akhir pembelajaran terdapat perubahan positif pada siswa melalui lembar observasi guru mengenai pemahaman materi termokimia dengan menggunakan metode drill (latihan) dimana siswa menjadi lebih aktif dalam bertanya.

\section{KESIMPULAN DAN SARAN Simpulan}

Berdasarkan penelitian ini maka dapat disimpulkan bahwa penerapan metode drill (latihan) pada materi termokimia SMA
Negeri 2 Kejuruan Muda Kabupaten Aceh Tamiang dapat meningkatkan hasil belajar siswa. Data hasil belajar dilihat dari nilai rata-rata kelas untuk pra kelas hanya 50,75, siklus 1 menjadi 63,50 dan siklus 2 meningkat menjadi 76,00. Pada tindakan pra siklus, siswa yang memiliki nilai dibawah KKM 70, sebanyak 35 siswa $(87,5 \%)$, siklus 1 sebanyak 26 siswa $(65,0$ $\%)$ dan 11 siswa $(27,5 \%)$ untuk siklus 2. Adapun hasil non tes pengamatan proses belajar menunjukkan peningkatan keaktifan siswa selama proses pembelajaran berlangsung .

\section{Saran}

Berdasarkan hasil penelitian dan pengembangan yang telah dilakukan saran yang dapat peneliti sampaikan yaitu untuk meningkatkan hasil belajar pada materi termokimia, perlu kiranya bagi para guru untuk melakukan pembelajaran dengan menggunakan model pembelajaran selain metode drill (latihan) ini. Selain itu guru hendaknya dapat menggunakan metode dan model presentasi yang lebih menarik lagi dengan mempersiapkan siswa terlebih dahulu terutama melakukan presentasi dengan menggunakan IT yang harus dipersiapkan terlebih dahulu oleh guru atau bersama-sama siswa.

\section{DAFTAR PUSTAKA}

Anni, C. T. (2004). Psikologi Belajar. Semarang: UPT UNNES Press

Chomaidi, P. H. dan Salamah. (2018.) Pendidikan dan Pengajaran. Jakarta: PT Grasindo

Darsono, dkk. (2000). Belajar dan Pembelajaran. Semarang: IKIP Semarang Press. 
Hamalik, O. (2003). Perencanaan Pengajaran Berdasarkan Pendekatan Sistem. Jakarta: Bumi Aksara.

Hamruni. (2012). Strategi Pembelajaran. Jogjakarta: Insan Madani

Majid, A. (2011). Perencanaan Pembelajaran. Cetakan kedelapan. Bandung: Rosda Karya

Rusman. (2010). Model-model Pembelajaran. Cetaakan keempat. Jakarta: PT RajaGrafindo Perkasa.

Rusman. (2012). Manajemen Kurikulum. Cetakan ke-4. Depok: Rajargafindo Persada

Sabri, A. (2010). Strategi Belajar Mengajar Micro Teaching. Cetakan 2I. Ciputat: Ciputat Press

Sani, R. A. (2014). Pembelajaran Saintifik untuk Implementasi Kurikulum 2013. Cetakan 2. Jakarta : Bumi Aksara

Siregar, E dan Nara, H. (2011). Teori Belajar dan Pembelajaran. Cetakan Kedua. Bogor: Penerbit Ghalia Indonesia

Slameto. (2003). Belajar dan Faktor-faktor yang Mempengaruhi. Cetakan keenam. Jakarta: PT Rineka Cipta

Sulistyorini. (2009). Evaluasi Pendidikan. Cetakan I. Yogyakarta: Teras

Syah, M. (2013). Psikologi Belajar.Cetakan ke-13. Jakarta: PT RajaGrafindo Persada
Uno, P. dan Muhammad, N. (2014). Belajar dengan Pendekatan PAILKEM: Pembelajaran Aktif, Inovatif, Lingkungan, Kreatif dan Menarik. Cetakan kelima. Jakarta: Bumi Aksara 